\title{
REVIEW
}

\section{Signalling, cycling and desensitisation of gonadotrophin-releasing hormone receptors}

\author{
C A McArdle, J Franklin, L Green and J N Hislop \\ University Research Centre for Neuroendocrinology, University of Bristol, Bristol BS2 8HW, UK \\ (Requests for offprints should be addressed to C A McArdle; Email: craig.mcardle@bristol.ac.uk)
}

\begin{abstract}
Sustained stimulation of G-protein-coupled receptors (GPCRs) typically causes receptor desensitisation, which is mediated by phosphorylation, often within the C-terminal tail of the receptor. The consequent binding of $\beta$-arrestin not only prevents the receptor from activating its $G$ protein (causing desensitisation), but can also target it for internalisation via clathrin-coated vesicles and can mediate signalling to proteins regulating endocytosis and mitogenactivated protein kinase (MAPK) cascades. GnRH acts via phospholipase C (PLC)-coupled GPCRs on pituitary gonadotrophs to stimulate a $\mathrm{Ca}^{2+}$-mediated increase in gonadotrophin secretion. The type I GnRH receptors (GnRH-Rs), found only in mammals, are unique in that they lack C-terminal tails and apparently do not undergo agonist-induced phosphorylation or bind $\beta$-arrestin; they are therefore resistant to receptor desensitisation and internalise slowly. In contrast, the type II GnRH-Rs, found in numerous vertebrates, possess such tails and show rapid desensitisation and internalisation, with concomitant receptor phosphorylation (within the C-terminal tails) or binding of $\beta$-arrestin, or both. The association with $\beta$-arrestin may also be important for regulation of dynamin, a GTPase that controls separation of endosomes from the plasma membrane. Using recombinant adenovirus to express GnRH-Rs in Hela cells conditionally expressing a dominant negative mutant of dynamin (K44A), we have found that blockade of dynamindependent endocytosis inhibits internalisation of type II
\end{abstract}

(xenopus) GnRH-Rs but not type I (human) GnRH-Rs. In these cells, blockade of dynamin-dependent internalisation also inhibited GnRH-R-mediated MAPK activation, but this effect was not receptor specific and therefore not dependent upon dynamin-regulated GnRH-R internalisation. Although type I GnRH-Rs do not desensitise, sustained activation of GnRH-Rs causes desensitisation of gonadotrophin secretion, and we have found that $\mathrm{GnRH}$ can cause down-regulation of inositol $(1,4,5)$ trisphosphate receptors and desensitisation of $\mathrm{Ca}^{2+}$ mobilisation in pituitary cells. The atypical resistance of the GnRH-R to desensitisation may underlie its atypical efficiency at provoking this downstream adaptive response. GnRH-Rs are also expressed in several extrapituitary sites, and these may mediate direct inhibition of proliferation of hormone-dependent cancer cells. Infection with type I GnRH-R-expressing adenovirus facilitated expression of high-affinity, PLC-coupled GnRH-R in mammary and prostate cancer cells, and these mediated pronounced antiproliferative effects of receptor agonists. No such effect was seen in cells transfected with a type II GnRH-R, implying that it is mediated most efficiently by a nondesensitising receptor. Thus it appears that the mammalian GnRH-Rs have undergone a period of rapidly accelerated molecular evolution that is of functional relevance to GnRH-Rs in pituitary and extrapituitary sites.

Journal of Endocrinology (2002) 173, 1-11

\section{Introduction}

Gonadotropin-releasing hormone $(\mathrm{GnRH})$ is a neuropeptide that acts via G-protein-coupled receptors (GPCRs) on gonadotrophs to control the secretion and synthesis of luteinising hormone and follicle-stimulating hormone (Conn \& Crowley 1994, Stojilkovic \& Catt 1995, Sealfon et al. 1997). The peptide first discovered
(pGlu-His-Trp-Ser-Tyr-Gly-Leu-Arg-Pro-Gly-NH ${ }_{2}$ ) is designated GnRH I, or simply GnRH, but most vertebrates express at least two forms. Typically, the highly conserved chicken GnRH-II (cGnRH-II or simply GnRH II) is found along with one or more additional forms of the peptide, and these distinct forms may play different physiological roles (e.g. regulation of reproduction and neuromodulation). The different forms of $\mathrm{GnRH}$ 
TYPE I

Mus musculus (mouse)

Homo sapiens (human)

TYPE II

Calithris jacchus (marmoset) type II

Macaca mulatta (rhesus monkey) type II

Cercopithecus aethiops (green monkey) type II

Xenopus laevis (clawed toad)

Clarias gariepinus (catfish)

Carassius auratus (goldfish) A

Anguilla japonica (Japanese eel)

Rana catesbeiana (African bullfrog) type I

Rana catesbeiana (African bulfrog) type II

Rana catesbeiana (African bullfrog) type III

\section{DPLIYGYFSL}

DPL IYGYESL

\begin{abstract}
DPLLYGAFTLGCRRGHQELSMDSSREEGSRRMFQQDIQALRQTEVQRTVTSRKAGETKDIPITSI DPLLYGAFTLGCQRGHQELSIDSSNEGSGRMLQQE I HALRQQEVQKTVTSRSAGETKGISITS I DPLLYGAFT EGCRRGHQELSIDSSKEGSGRMLQQEIHALRQQEVQKTVTSRSAGETKGISITS I DPLVYGLYTPSEKEDLRSWIRRVSTLLSRKEKNSKQLAGSELNIKDLTSMEGPTSTAVTMQSVE DPVIYGFFTPSERADLSRCECWRNQNASAKSLPHFSGHRREVSGEAESDLGSGDQPSGQ DPVIYGLYTPSERADLARCWRCRT PAESPRSLDRI PHENTSPTRPA DPVIYGLYT PSFRADLAVCWECRPODSSPKSLDRLSARQGNPSAEQESDAPSVDQMRANEE DPITYGLFTIHERKSLQRYCGGRRTSDADTSSSVTGSERCSMSS FRAKKMIVLNQEL QVLQSCNGNENNPELRLNGLGTSCL

DPLVYGLYTPSFKEDLRTWLRRLGGLITRKAKNSKPLADSEMNIKDETSMDGPTTTATTVQSVE DPIIYGLFTIHERREIRRVCRCATQGKDADATSLGTGSERISTAAVPLKRSAGASGGSC KFDLEVTGVGLHSGKCEHCKRQIVES EM
\end{abstract}

Figure 1 C-terminal amino acid sequences of 10 cloned GnRH-Rs, aligned according to the putative seventh transmembrane regions (bold). The C-terminal sequences of all known type I receptors (e.g. cow, pig, rat, sheep, horse, dog, marmoset type I and possum) are identical to those of the mouse and human. In contrast, all cloned type II receptors have C-terminal tails with potential phosphorylation sites. Sequences from PubMed (nucleotide).

have apparently evolved in parallel with distinct forms of the GnRH receptor (GnRH-R), and the known receptors can be broadly divided into two groups (Sealfon et al. 1997). The type I GnRH-Rs have greater affinity for GnRH-I than for GnRH-II and do not possess C-terminal tails; this group contains all known mammalian GnRH-Rs except for the recently described primate type II GnRH-R (Millar et al. 2000, 2001, Neill et al. 2001a). Type II GnRH-Rs have greater affinity for the GnRH-II and possess C-terminal tails of varying length; this group contains all the known receptors from non-mammalian vertebrates (catfish, goldfish, chicken, goldfish, Xenopus, etc.) in addition to the type II primate GnRH-Rs. Types I and II GnRH-Rs show considerable sequence homology in a number of key areas (Troski et al. 2000), including conserved disulphide bridges between the first and second extracellular loops, and conservation of amino acids implicated in ligand binding and effector coupling. There are, however, important structural differences: for example, type I GnRH-R function is dependent upon interacting asparagine and aspartate residues in transmembrane regions II and VII (Asn ${ }^{87}$ and $\mathrm{Asp}^{318}$ in the hGnRH-R), but these are not conserved in type II GnRH-R (where aspartic acid may be found in both positions). Nevertheless, the most striking feature is the absence of C-terminal tails in type I GnRH-R (Fig. 1). Such tails are present in all other cloned GPCRs, and are crucial for receptor coupling and regulation. Their absence from type I mammalian GnRH-R implies that these receptors have undergone a (relatively) recent period of rapidly accelerated molecular evolution, and provides a unique opportunity for comparative studies investigating GPCR structure and function within the context of normal (non-mutated) receptors. The purpose of this review is to outline the roles attributed to C-terminal tails of GPCRs and the likely functional consequences of their absence or presence in GnRH-Rs.

\section{Functional roles of GPCR C-terminal tails}

GPCRs act via heterotrimeric $G$ proteins to regulate effector proteins including phospholipase C (PLC) and adenylyl cyclase. On sustained or intense stimulation, GPCR-mediated responses typically desensitise. Desensitisation is defined as a waning of response in the presence of a constant, or repeated, stimulus; adaptive responses at the level of the receptor provide the most rapid and well described cause of such desensitisation (Zhang et al. 1997, Ferguson 2001). Activation of GPCRs is typically followed by their desensitisation and internalisation, and these processes involve receptor phosphorylation (Fig. 2). This phosphorylation is stimulated by agonist binding, is typically rapid (seconds to minutes) and may be mediated by specific G-protein receptor kinases (GRKs), by second messenger-regulated kinases (e.g. protein kinase $\mathrm{C}$ (PKC) or PKA), or by casein kinases (Tobin et al. 1997, Hanyaloglu et al. 2001). For many GPCRs, this phosphorylation facilitates or stabilises the association with $\beta$-arrestin, which stearically hinders G-protein binding and thereby prevents effector activation (Zhang et al. 1997, Ferguson 2001). As this effect is seen within seconds to minutes, and is specific to the activated receptor, it is termed rapid homologous receptor desensitisation, or simply receptor desensitisation.

$\beta$-Arrestin also acts as an adapter, targeting desensitised GPCRs for internalisation (Goodman et al. 1996, Ferguson 2001). GPCRs are internalised from the cell surface by endocytosis, most often via clathrin-coated vesicles (CCVs). The formation of these vesicles is typically controlled by a dynamin collar, which separates the vesicle from the plasma membrane by pinching off (or stretching) the neck of the vesicle (Schmid 1998). After internalisation, the receptors are either recycled to the cell surface or targeted to lysosomes for degradation. In addition to 
GPCRs, $\beta$-arrestins bind several proteins involved in receptor cycling and signalling. Indeed, $\beta$-arrestins are believed to function as scaffolds, mediating the assembly of a complex including the GPCR and a number of proteins (Lefkowitz 1996, Miller \& Lefkowitz 2001) controlling endocytic receptor internalisation (such as activator protein (AP)-2 and clathrin) and proteins mediating mitogenactivated protein kinase (MAPK) activation (such as $\mathrm{Src}$ ). These last proteins are of particular interest, because it now appears that mechanisms previously thought of in terms of switching receptor signalling off may actually be switching between two distinct modes of receptor signalling, because a receptor desensitised in terms of heterotrimeric G-protein activation may actually be activated in terms of $\beta$-arrestin-mediated MAPK activation. Binding and activation of $\beta$-arrestin involve association with several sites on GPCRs (Ferguson 2001), but the amino acids phosphorylated to facilitate $\beta$-arrestin binding are most often located within the C-terminal tail of the GPCR. This region is therefore believed to have a crucial role in agonist-stimulated desensitisation, internalisation, downregulation and $\beta$-arrestin-mediated signalling.

\section{Functional relevance of $\mathrm{C}$-terminal tails in GnRH-Rs}

It has long been known that that sustained exposure to GnRH causes desensitisation of GnRH-stimulated gonadotrophin secretion and that this is associated with receptor down-regulation and internalisation of GnRH-Rs via coated pits (Jennes et al. 1983, 1986, Conn et al. 1987). Indeed, exploitation or avoidance of such effects is crucial for the clinical applications of $\mathrm{GnRH}$ analogues (Barbieri 1992, Conn \& Crowley 1994). It had therefore been anticipated that desensitisation and internalisation of GnRH-R would follow the model depicted in Figure 2, but this proved not to be so. As GnRH-Rs are coupled via $G_{\mathrm{q} / 11}$ to PLC $\beta 1$, their activity can be measured by quantification of $\left[{ }^{3} \mathrm{H}\right]$ inositol phosphate (IP) accumulation (in cells pre-labelled with $\left[{ }^{3} \mathrm{H}\right]$ inositol and stimulated in the presence of $\left.\mathrm{LiCl}\right)$. When GnRH-stimulated $\left[{ }^{3} \mathrm{H}\right] \mathrm{IP}$ accumulation was measured in the gonadotroph-derived $\alpha \mathrm{T} 3-1$ cell line (Davidson et al. 1994), the initial rate of $\left[{ }^{3} \mathrm{H}\right] \mathrm{IP}$ accumulation was maintained for at least $90 \mathrm{~min}$. As such accumulation is typically not maintained beyond $1 \mathrm{~min}$ with desensitising receptors, these data implied that the endogenous murine GnRH-Rs of these cells do not desensitise rapidly. GnRH also caused a sustained increase in inositol $(1,4,5)$ trisphosphate $\left(\mathrm{IP}_{3}\right)$ and a sustained reduction in phosphatidylinositol bisphosphate $\left(\mathrm{PIP}_{2}\right)$ mass in these cells, in contrast to the transient responses typically seen with receptors that do desensitise rapidly (Willars et al. 1998). Moreover, the resistance of these receptors to desensitisation is clearly a consequence of receptor struc- ture (rather than cell type), because type I GnRH-Rs have subsequently been shown not to desensitise in numerous systems (McArdle et al. 1995, 1996, 1999, Heding et al. 1998, 2000, Forrest-Owen et al. 1999, Willars et al. 1999, 2001, Hislop et al. 2000, Neill et al. 2001b), whereas other GPCRs have been shown to desensitise rapidly in $\alpha \mathrm{T} 3-1$ cells (McArdle et al. 1996, Evans et al. 1997, McArdle \& Forrest-Owen 1997, Willars et al. 1998).

The obvious question raised by the lack of desensitisation of these endogenous type I GnRH-Rs is whether this can be attributed to the lack of the C-terminal tail. Unlike type I GnRH-Rs, $\left.{ }^{3} \mathrm{H}\right] \mathrm{IP}$ responses mediated by catfish GnRH-R do rapidly desensitise (Heding et al. 1998, Blomenrohr et al. 1999, Willars et al. 1999), and these receptors undergo agonist-induced phosphorylation within the C-terminal tail. They also mediate agonistinduced translocation of green fluorescent protein (GFP)tagged $\beta$-arrestin from the cytosol to the plasma membrane. Such translocation provides a marker for receptor activation and phosphorylation. Moreover, the internalisation of these receptors is slowed by removal of a phosphate acceptor site from the C-terminus (Blomenrohr et al. 1999) and accelerated by increasing expression of $\beta$-arrestin. Thus it appears that these type II GnRH-Rs undergo agonist-induced phosphorylation with consequent $\beta$-arrestin binding, desensitisation and targeting of the desensitised receptors for internalisation via CCVs, as outlined in the general model (Fig. 2). In contrast, rat GnRH-Rs do not desensitise rapidly, and do not undergo agonist-induced phosphorylation or cause $\beta$-arrestin-GFP translocation. They do show agonist-induced internalisation, but this is much slower and is not influenced by expression of $\beta$-arrestin (Heding et al. 1998, 2000, Vrecl et al. 1998, Willars et al. 1999). When the C-terminal tail of the catfish GnRH-R was added to the rat GnRH-R, this chimeric receptor did show agonistinduced phosphorylation and rapid desensitisation (Willars et al. 1998). The lack of desensitisation, phosphorylation and $\beta$-arrestin translocation with type I GnRH-R stands in apparent contrast to studies showing that overexpression of GRKs or $\beta$-arrestin can inhibit GnRHstimulated $\mathrm{IP}_{3}$ responses in (COS) cells (Neill et al. 1998) and that over-expression of a GRK can inhibit GnRHstimulated gonadotrophin secretion from primary cultures of pituitary cells (Neill et al. 1999). However, it is important to recognise that these inhibitory effects were seen at all time points and without the change in temporal profile expected if receptor desensitisation (and the consequent waning of response) had been stimulated. This is in stark contrast to classic studies of $\beta_{2}$-adrenergic receptors in which desensitisation was revealed by the diminution of rates of cAMP accumulation during stimulation, and prevention of receptor phosphorylation prevented the waning of the response on maintained stimulation (Liggett et al. 1989). Thus, although type I GnRH-R signalling can be inhibited by GRK or 


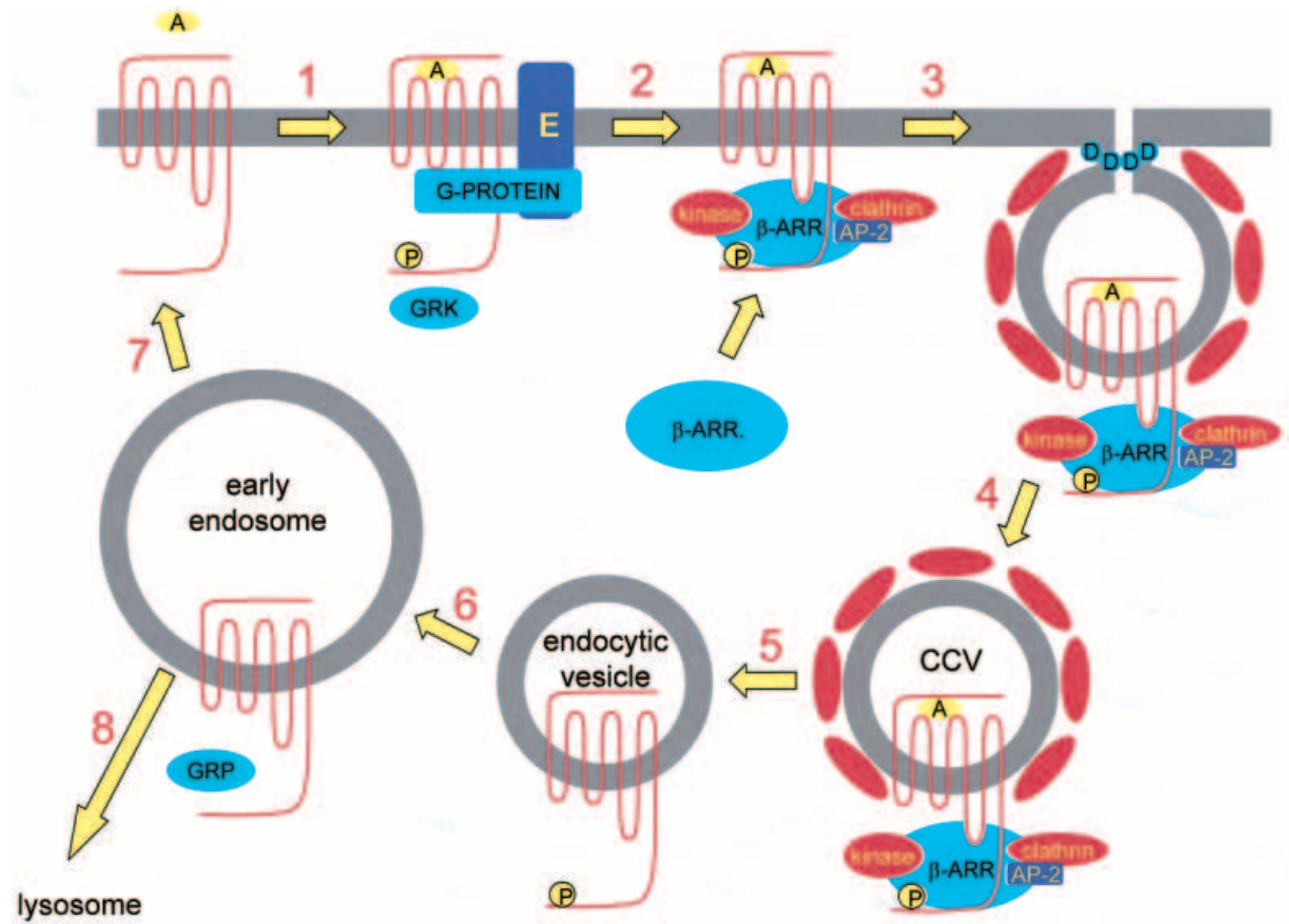

Figure 2 Rapid homologous desensitisation and cycling of G-protein-coupled receptors (GPCRs) - general model. (1) Agonist (A) binding stabilises the receptor conformation that activates the heterotrimeric G-protein which, in turn, activates its effector(s) (E). (2) The active receptor conformation is a preferred substrate for phosphorylation (e.g. by a G-protein receptor kinase (GRK)), which facilitates binding of $\beta$-arrestin ( $\beta$-ARR). This prevents further G-protein activation. (3) The $\beta$-arrestin has recognition sites for clathrin, AP-2 and various kinases, in addition to distinct sites for binding to phosphorylated and unphosphorylated sites within the GPCR. Binding to clathrin and AP-2 targets the $\beta$-arrestin-bound (desensitised) receptor for internalisation via clathrin-coated vesicles (CCVs). (4) The vesicle is pinched off from the membrane by a dynamin collar (D), yielding a CCV containing GPCRs. These may remain complexed (via $\beta$-arrestin) to other signalling proteins after internalisation. (5) and (6) Coat proteins are removed from the CCV and the uncoated vesicle fuses with early endosome. During these processes, the ligand dissociates from the receptor, the GPCR-associated proteins are removed, and the GPCR is dephosphorylated. The control and sequence of these events is poorly understood, although dephosphorylation may involve specific GPCR phosphatases (GRP). (7) and (8) The dephosphorylated GPCR is then cycled (via transport vesicles) to the lysosome for degradation (receptor down-regulation) or to the plasma membrane (resensitisation). P, phosphate.

$\beta$-arrestin expression, this inhibition does not necessarily reflect enhanced or accelerated receptor desensitisation (Neill et al. 1998).

Although other GnRH-Rs have not been extensively compared, we have found that human GnRH-Rs are resistant to desensitisation, internalise slowly and do not cause $\beta$-arrestin-GFP translocation, as compared with xenopus GnRH-Rs, which desensitise and internalise rapidly (Hislop et al. 2000) and do translocate $\beta$-arrestin/ GFP (Fig. 3). Most of our own comparative work has been performed using recombinant adenovirus containing GnRH-R DNA, a system that facilitates expression of these receptors at defined density in $\alpha \mathrm{T} 4$ cells (a gonadotroph lineage cell line lacking endogenous GnRH-R). This has enabled us to establish that the functional distinctions between these type I and type II GnRH-Rs (differing propensity for desensitisation and internalisation) are maintained in gonadotroph-lineage cells, do not reflect differences in receptor density (below) and are observed in the presence of physiological receptor numbers (Hislop et al. 2000). Finally, a type II primate GnRH-R recently was shown to desensitise under conditions in which a type I human GnRH-R did not (Neill et al. 2001a). Thus, although other features may well prove relevant, the 


\section{Xenopus GnRH-R}
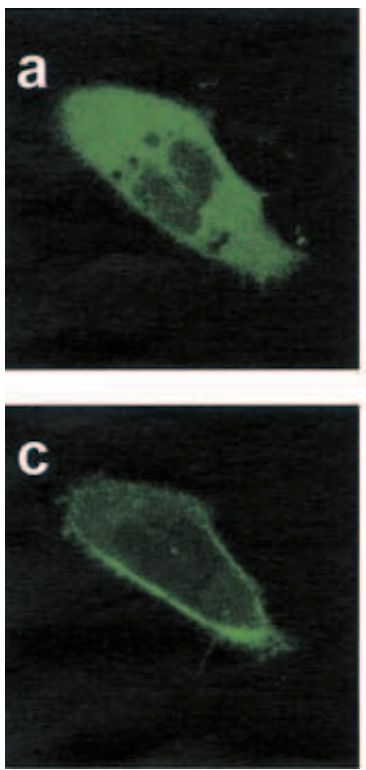
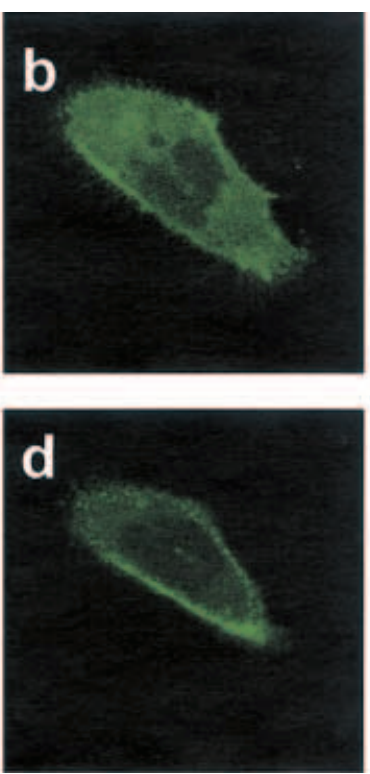

Human GnRH-R
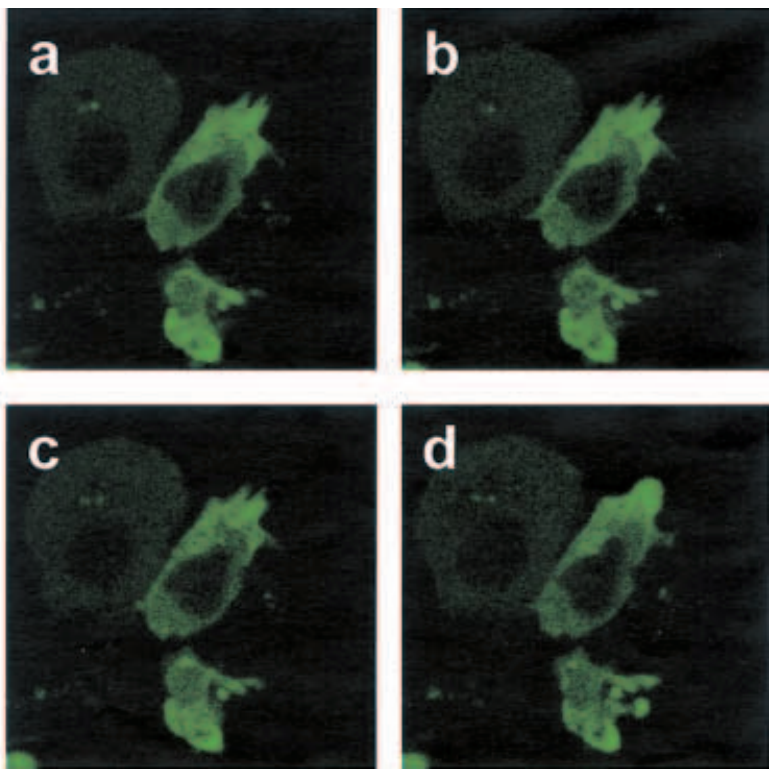

Figure $3 \mathrm{GnRH}-\mathrm{R}$ mediation of $\beta$-arrestin translocation. As agonist-induced phosphorylation of GPCRs facilitates or stabilises the binding of $\beta$-arrestin, the consequent translocation of $\beta$-arrestin-green fluorescent protein (GFP) fusion proteins to membranes containing GPCRs can be used as a marker for receptor activation, phosphorylation and desensitisation. The Figure shows confocal images of COS-1 cells transfected with $\beta$-arrestin-2-GFP and either xenopus GnRH-Rs (type II receptor, left panel) or human GnRH-Rs (type I receptor, right panel) at 0, 5, 10 and $15 \mathrm{~min}(\mathrm{a}-\mathrm{d})$ after stimulation with GnRH (human GnRH-R) or cGnRH-II (xenopus GnRH-R). Note that the type II receptor mediates $\beta$-arrestin translocation, whereas the type I receptor does not.

existing data are consistent with the suggestion (Davidson et al. 1994) that absence of C-terminal tails in type I GnRH-Rs underlies their atypical resistance to desensitisation. Moreover, as primates may express type I and type II receptors (Millar et al. 2000, 2001, Neill et al. 2001a), these functionally distinct receptors may exist in the same species and cells.

\section{Desensitisation downstream of the GnRH-R}

GnRH-stimulated gonadotrophin secretion shows pronounced desensitisation, whereas type I mammalian GnRH-Rs do not. Accordingly, desensitisation of GnRH-stimulated GnRH secretion must reflect downstream adaptive responses, and gonadotrophs may well provide a unique opportunity for investigation of such responses, in the absence of receptor desensitisation. In exploring this, we have found that sustained stimulation of $\alpha \mathrm{T} 3-1$ cells with GnRH causes a pronounced desensitisation of $\mathrm{Ca}^{2+}$ responses (McArdle et al. 1995, 1996). In control cells, GnRH causes a spike-plateau type increase in the cytosolic $\left[\mathrm{Ca}^{2+}\right]_{\mathrm{I}}$ concentration in which the spike phase reflects $\mathrm{IP}_{3}$-mediated mobilisation of $\mathrm{Ca}^{2+}$ from intracellular stores and the plateau phase reflects entry of $\mathrm{Ca}^{2+}$ across the plasma membrane (McArdle et al. 1992), as previously reported for primary cultures of rat pituitary cells (Naor et al. 1988). Focusing on the mobilisation of intracellular $\mathrm{Ca}^{2+}$, we observed a relatively rapid desensitisation of $\mathrm{GnRH}$-stimulated $\mathrm{Ca}^{2+}$ mobilisation (Fig. 4). As this occurs in the absence of receptor desensitisation and is not attributable to depletion of the intracellular $\mathrm{Ca}^{2+}$ pool, it appears to reflect a reduction in the efficiency with which $\mathrm{IP}_{3}$ mobilises $\mathrm{Ca}^{2+}$ from this pool (McArdle et al. 1996). This effect was associated with, and apparently dependent upon, a GnRH-stimulated reduction in the number of $\mathrm{IP}_{3}$ receptors $\left(\mathrm{IP}_{3}-\mathrm{Rs}\right)$ (Willars et al. 2001). Sustained activation of several PLC-activating GPCRs has been shown to cause $\mathrm{IP}_{3}-\mathrm{R}$ down-regulation, an effect attributed to the ligand-stimulated ubiquitinylation and consequent proteolysis of the activated $\mathrm{IP}_{3}-\mathrm{R}$ (Wojcikiewicz \& Oberdorf 1996, Zhu \& Wojcikiewicz 2000). However, this effect is typically slow and modest as compared with the pronounced and rapid effect of GnRH (e.g. 80\% reduction within 20-30 min). Thus it appears that this receptor, which is atypically resistant to desensitisation, is atypically efficient at provoking this novel form of post-receptor desensitisation (Willars et al. 2001). It is important to recognise, however, that the relevance of this effect to desensitisation of gonadotrophin secretion has not been established. Other effects (such as depletion of releasable gonadotrophin pools, down-regulation of GnRH-R and inhibition of 


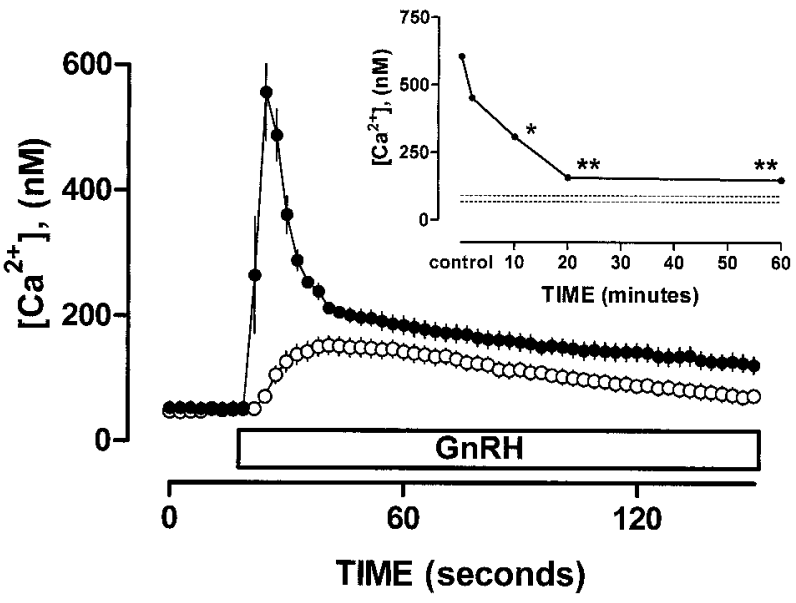

Figure 4 Desensitisation of $\mathrm{Ca}^{2+}$ responses in pituitary cells. Main panel: Cytosolic $\mathrm{Ca}^{2}$ concentration, measured by video imaging in $\alpha \mathrm{T} 3-1$ cells stimulated (bar), with $10^{-7} \mathrm{M} \mathrm{GnRH}$. In control cells $(-), G n R H$ caused a characteristic spike-plateau type response, but in cells pretreated for 60 min with $10^{-7} \mathrm{M}$ GnRH $(\bigcirc)$, the spike response was lost and the plateau phase was reduced. Inset: The relationship between duration of pretreatment and amplitude of the spike response on subsequent stimulation. From McArdle et al. 1996, with permission.

gonadotrophin synthesis) may well prove to be more important for long-term desensitisation of gonadotrophin secretion in vivo.

\section{$\beta$-Arrestin-mediated GPCR signalling}

As noted above, $\beta$-arrestins can act as scaffolds, facilitating the interaction of phosphorylated GPCRs with other regulatory proteins (Lefkowitz 1996, Miller \& Lefkowitz 2001). The $\beta$-arrestin-mediated coupling of GPCRs to clathrin, AP-2 and N-ethylamide sensitive factor (NSF) directs GPCRs for internalisation via CCVs, and the binding to kinases such as c-Jun N-terminal kinase, ASK1, Src, extracellular-signal regulated kinase (ERK) and Raf can mediate MAPK signalling in a heterotrimeric G-protein-independent manner (Lefkowitz 1996, Miller \& Lefkowitz 2001). These effects may be interrelated, because Src-mediated phosphorylation of dynamin can be requisite for receptor internalisation (Luttrell et al. 2001) and blockade of dynamin-dependent receptor internalisation can inhibit GPCR-stimulated MAPK activation (Daaka et al. 1998). The implication is not only that the 'desensitised' receptor may actually signal via $\beta$-arrestin, but also that it may continue to do so after receptor internalisation. Such signalling may differ (quantitatively and qualitatively) from that of the cell surface receptor (Vieira et al. 1996). Such observations prompted us to compare ERK2 phosphorylation mediated by human and xenopus GnRH-R in Hela cells (Hislop et al. 2001). This revealed no difference in amplitude or time-course of response, so it is unlikely that $\beta$-arrestin mediates significant xenopus GnRH-R-mediated MAPK activation in this system. Indeed, ERK2 activation in $\alpha \mathrm{T} 3-1$ cells is largely attributed to PKC activation (Naor et al. 2000), and kinetics of the response are determined largely by phosphatase activation (Zhang et al. 2001). This may therefore hold true for responses to both receptors in Hela cells.

Because $\beta$-arrestin-mediated recruitment of Src may also underlie activation of dynamin (Lefkowitz 1996, Miller \& Lefkowitz 2001), the dynamin-dependence of GnRH-R internalisation has also been explored by expression of GnRH-Rs and GTPase-deficient mutants of dynamin, which can act as dominant negatives, inhibiting dynamin-dependent receptor internalisation (Vieira et al. 1996, Heding et al. 2000). In COS cells, co-transfected with GnRH-R and a GTPase-deficient mutant of dynamin (Heding et al. 2000), the mutant had a more pronounced inhibitory effect on the internalisation of catfish GnRH-R than on that of rat GnRH-R (e.g. approximately $67 \%$ and $23 \%$ inhibition at 60 min respectively). Using recombinant adenovirus to express human and xenopus GnRH-R in Hela cells conditionally expressing the same dominant-negative mutant (K44A) of dynamin (Hislop et al. 2001), we have obtained similar results, except that the internalisation of the type I receptor was uninfluenced by prevention of dynamin-dependent internalisation (Fig. 5). Thus it appears that the C-terminal tail not only facilitates agonist-induced $\beta$-arrestin translocation, but may also target the receptor for dynamindependent internalisation, precisely as expected if $\beta$-arrestin mediates communication between the receptor and dynamin (Miller \& Lefkowitz 2001). Recent studies have demonstrated that inhibition of dynamin can reduce GnRH-stimulated ERK activation in $\alpha \mathrm{T} 3-1$ cells (Bernard et al. 2001), and we have found that the dominant-negative K44A dynamin inhibits ERK2 phosphorylation mediated by human or xenopus GnRH-R. This occurs in spite of the fact that the dynamin mutant only inhibits internalisation of the xenopus GnRH-R (Hislop et al. 2001) and this uncoupling clearly implies that the dynamin-dependence of ERK2 activation is unrelated to dynamin-dependent receptor internalisation. Indeed, it most probably reflects the dynamin-dependence of Ras activation, as shown in $\alpha \mathrm{T} 3-1$ cells (Bernard et al. 2001) or of MAPK kinase signalling to ERK2 (Kranenburg et al. 1999). We have also found that the ERK2 activation stimulated by a protein kinase C-activating phorbol ester is inhibited by K44A dynamin (Hislop et al. 2001), confirming that the site of dynamin dependence lies distal to the GnRH-R and is therefore not specific to receptor-mediated responses.

The implication of the data above is that type I GnRH-Rs not only have reduced rates of desensitisation and internalisation, but may also have a reduced repertoire 

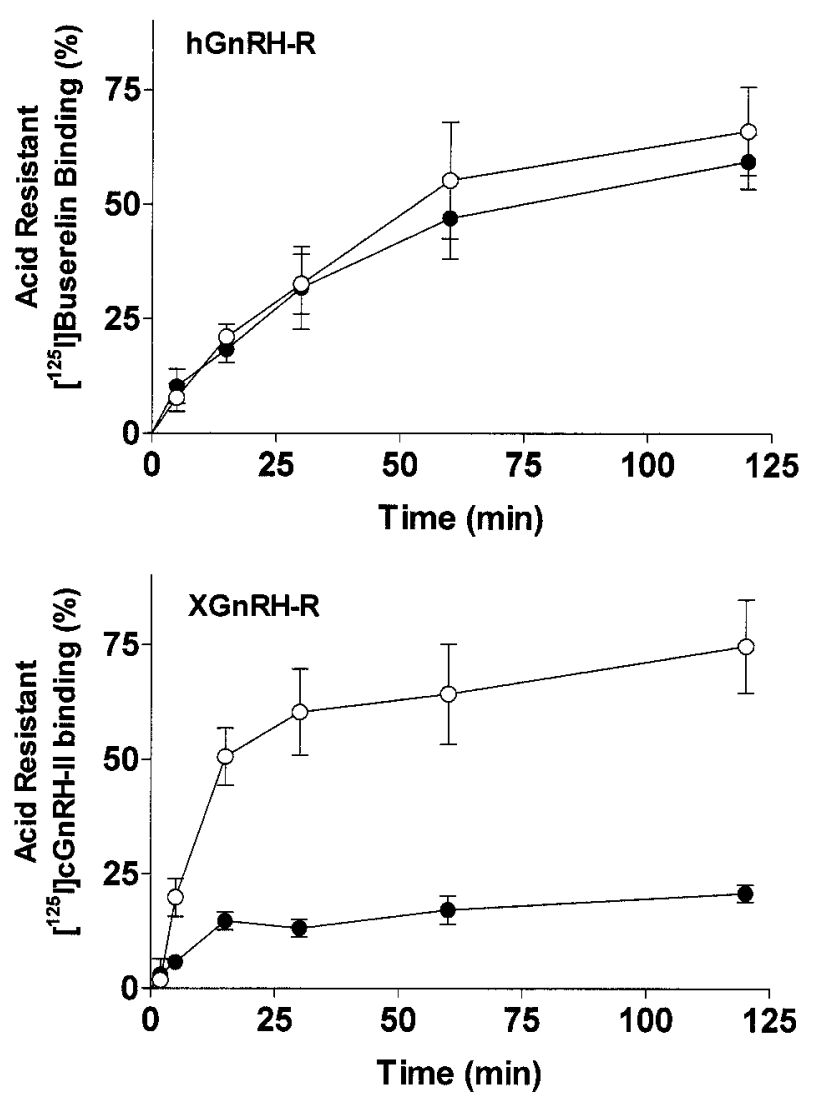

Figure 5 Dynamin dependence of GnRH-R internalisation. Receptor internalisation was measured by radioligand binding $\left(37^{\circ} \mathrm{C}\right.$ ) in $\mathrm{K} 44 \mathrm{~A}$ Hela cells transfected (infection with recombinant adenovirus) with either human GnRH-R (type I, hGnRH-R) or xenopus GnRH-R (type II, XGnRH-R). These cells express a dominant-negative mutant of dynamin (K44A) under control of the tet-off system: when cultured with tetracycline, they do not express the transgene, but dynamin-dependent internalisation can be inhibited simply by omitting the tetracycline. Internalisation of the hGnRH-R (upper panel) was relatively slow in control cells $(\bigcirc)$ and was not influenced by omission of tetracycline $(\bullet)$, whereas internalisation of the XGnRH-R (lower panel) was rapid in control cells $(\bigcirc)$ and was dramatically reduced when dynamin-dependent internalisation was blocked (0). Data from Hislop et al. 2001, with permission.

of signalling possibilities, as compared with type II receptors. Although type I GnRH-Rs would not be expected to signal via $\beta$-arrestin, it seems likely that $\beta$-arrestinmediated signalling to dynamin occurs with type II GnRH-Rs. $\beta$-Arrestin-mediated signalling to MAPK could conceivably also occur with type II GnRH-Rs, but has not yet been demonstrated. Indeed, heterotrimeric G-protein-mediated signalling to MAPK pathways may well mask any gross differences in $\beta$-arrestin-mediated MAPK signalling via type I and type II GnRH-Rs (Fig. 6).

\section{GnRH-Rs in hormone-dependent cancers}

GnRH and GnRH-Rs are also found in many gonadal steroid-dependent cancers, including those of the breast, endometrium, prostate and ovary (Eidne et al. 1985, Miller et al. 1985, Emons et al. 1993, 1997, 1998, Emons \& Schally 1994, Imai et al. 1997, Limonta et al. 1999, 2001, Schally 1999, Schally \& Nagy 1999, Imai \& Tamaya 2000, Grundker et al. 2001). Interest in these receptors stems primarily from the fact that GnRH analogues and cytotoxic derivatives of $\mathrm{GnRH}$ analogues can inhibit proliferation of cancer-derived cell lines, suggesting that such direct effects may contribute to the beneficial effects of GnRH analogues in cancer therapy. Although GnRH-R transcripts detected in various cancer cells are identical to those of the pituitary (Kakar et al. 1994), the receptors may differ functionally. In binding studies, pituitary GnRH-Rs have high affinity for agonists such as buserelin (nM $K_{\mathrm{d}}$ values), whereas the majority of GnRH-Rs in extrapituitary sites have low affinity ( $\mu \mathrm{M} K_{\mathrm{d}}$ values). Pronounced differences in signalling and ligand specificity have also been reported. Whereas GnRH-Rs in gonadotrophs act via $G_{\mathrm{q} / 11}$ to stimulate PLC, and via PKC to stimulate MAPK, those in ovarian and endometrial cancer cell lines appear not to activate PLC and, in the presence of epidermal growth factor (EGF), actually inhibit ERK phosphorylation (Emons et al. 1997, 1998). Although GnRH-Rs are believed not to activate $G_{i}$ in gonadotrophs, a $G_{i}-$ mediated activation of protein tyrosine phosphatase(s) may underlie antiproliferative effects of $\mathrm{GnRH}$ analogues in human cancer cells (Grundker et al. 2001). Moreover, the antiproliferative effects of GnRH-R agonists in some cancer cell models can be mimicked by analogues that are competitive antagonists at pituitary GnRH-Rs (Emons et al. 1997, 1998), suggesting that the agonist/antagonist dichotomy established for pituitary GnRH-Rs may not apply in extrapituitary sites.

With the wide range of models and responses explored, it is difficult to generalise about mechanisms of action, but there are three obvious possibilities. The first is that GnRH-R activation is inhibitory, such that activation of this receptor slows cancer cell proliferation. This is perhaps the most intriguing possibility, because of the major differences reported between GnRH-Rs and response characteristics in pituitary and extrapituitary sites. This interpretation requires that the GnRH-R displays extreme context- or density-dependence, and begs the question of the molecular reasons for such dependence. The second possibility is that locally produced $\mathrm{GnRH}$ actually stimulates cancer cell proliferation, and that this is prevented by GnRH-R antagonists or by down-regulation with agonists. This provides a simple explanation for inhibition of cancer cell proliferation by antagonists, but is only applicable where endogenous agonist is known to support proliferation. The third possibility is that effects of $\mathrm{GnRH}$ analogues are mediated by additional forms of the 


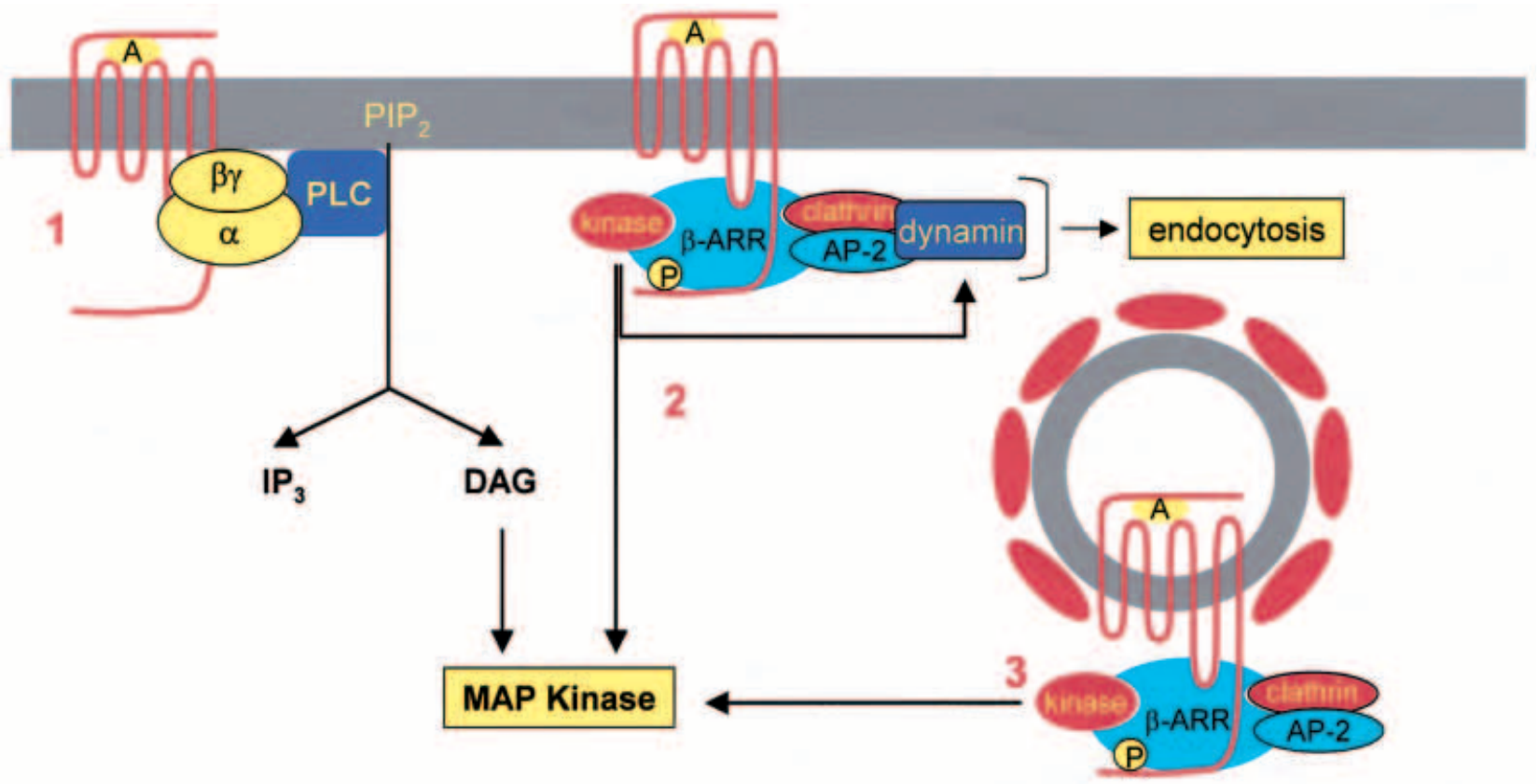

Figure 6 Possible GnRH-R signalling modes. It is important to recognise that type I GnRH-R would not be expected to show $\beta$-arrestin-mediated signalling. Only the first of these modes of signalling has been established for any GnRH-R, and the second and third could presumably only be available to type II receptors. Thus the molecular evolution of these receptors may well have dramatically limited their signalling repertoire. (1) G-protein-mediated signalling. In pituitary gonadotrophs, the heterotrimeric G-protein is $\mathrm{G}_{\mathrm{q} / 11}$ and the effector is PLC $\beta 1$. This cleaves phosphatidylinositol 4,5-bisphosphate $\left(\mathrm{PIP}_{2}\right)$, producing inositol trisphosphate $\left(\mathrm{IP}_{3}\right)$, which mobilises Ca ${ }^{2+}$ and thereby acutely regulates exocytosis. It also yields diacylglycerol (DAG), which activates PKC, feeding in to mitogen-activated protein kinase (MAPK) regulation and consequent regulation of gene expression. (2) $\beta$-Arrestin-mediated signalling. Receptor phosphorylation facilitates $\beta$-arrestin binding. The $\beta$-arrestin acts as a scaffold, mediating effects on proteins regulating endocytosis and on kinases in MAPK pathways. One of these ( $\mathrm{Src}$ ) may also control dynamin-dependent endocytosis. (3) $\beta$-Arrestin-mediated signalling after internalisation. Proteins on the $\beta$-arrestin scaffold may continue to signal after internalisation, providing a mechanism for cellular compartmentalisation of signalling. For other receptors, signals carried by the plasma membrane and internalised receptors can differ both quantitatively and qualitatively (Vieira et al. 1996). A, agonist; P, phosphate.

GnRH-R (or related receptors). The recently cloned primate type II GnRH-R is the obvious candidate, because it is expressed outside the pituitary and because of the known differences in ligand specificity between primate type I and II GnRH-Rs (Millar et al. 2000, 2001, Neill et al. 2001a). Moreover, it has been shown that antagonists of type I GnRH-Rs can act as agonists at type II GnRH-Rs (Sun et al. 2001).

We have begun to examine the possible contextdependence of GnRH-R signalling by comparing responses of pituitary GnRH-Rs with those in cell lines derived from hormone-dependent cancers. In human breast cancer cells (MCF-7), we have found too few endogenous GnRH-Rs for pharmacological characterisation and no effect of $\mathrm{GnRH}$ (or analogues) on proliferation of control cells (Everest et al. 2001). In contrast, when recombinant adenovirus was used to express type I GnRH-Rs, they were pharmacologically indistinguishable from those in the pituitary and were able to mediate pronounced antiproliferative effects of $\mathrm{GnRH}-\mathrm{R}$ agonists (Fig. 7). We have subsequently obtained similar results in several hormone-dependent cancer cell lines
(T47D, PC3, Du145 and Ishikawa; data not shown). This effect may be specific for extrapituitary GnRH-R, because we have observed no inhibition of proliferation by $\mathrm{GnRH}$ in gonadotroph-derived $\alpha \mathrm{T} 3-1$ cells (Schomerus et al. 1994), although others have found that $\left(\mathrm{D}-\mathrm{Lys}^{6}\right) \mathrm{GnRH}$ inhibits the proliferation of these cells (Kakar et al. 1997). This peptide also inhibits proliferation of human embryonic kidney cells transfected with human GnRH-Rs (Kakar 1998), demonstrating that GnRH-R-mediated inhibition of proliferation is not confined to hormone-dependent cancer cells.

Although such studies can clearly not reveal the mechanism of action of any endogenous GnRH-R in hormone-dependent cancer cells, they have unambiguously demonstrated that such cells are capable of expressing high-affinity GnRH-Rs that can distinguish between agonists and antagonists, are positively coupled to PLC and ERK2, and do mediate inhibition of proliferation (Everest et al. 2001). Interestingly, inhibition of proliferation in these mammary cancer cells requires sustained stimulation with agonists and would therefore be expected to be 


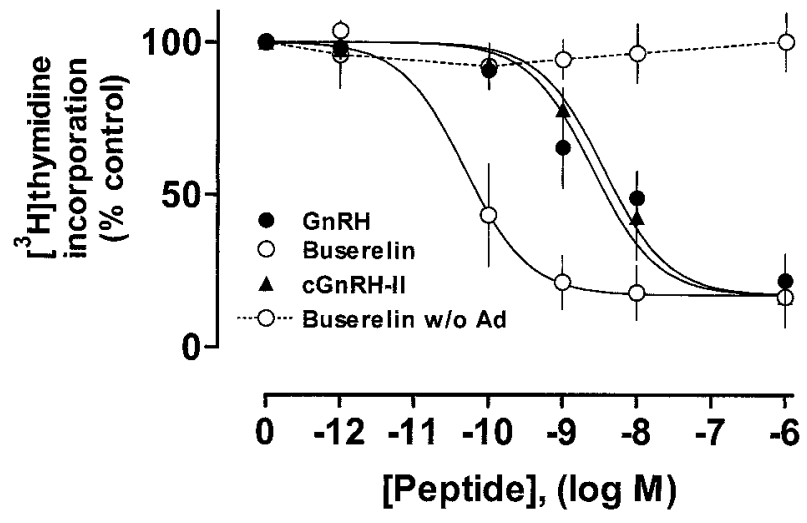

Figure 7 Transfection with type I GnRH-Rs facilitates antiproliferative effects of GnRH analogues in human breast cancer cells. MCF7 cells were infected with recombinant adenovirus (Ad) expressing sheep GnRH-R at a titre of 0 (control cells without (w/o) adenovirus) or 100 plaque-forming units per cell. The indicated peptides were added approximately $24 \mathrm{~h}$ later and the cells were then incubated for 5 days, before measurement of $\left[{ }^{3} \mathrm{H}\right]$ thymidine incorporation. All three peptides caused a concentration-dependent inhibition of $\left[{ }^{3} \mathrm{H}\right]$ thymidine incorporation in adenovirus-infected cells, whereas none had any measurable effect in control cells receiving no adenovirus or receiving an 'empty' adenovirus (dotted line, and data not shown). Data from Everest et al. 2001, with permission.

susceptible to modulation by receptor desensitisation. Indeed, we have found that GnRH-II can inhibit mammary cancer cell proliferation by virtue of its cross-reactivity at a type I GnRH-R, but fails to do so in cells expressing a type II (xenopus) GnRH-R, in spite of its greater affinity for the latter receptor and the greater levels of expression of xenopus GnRH-R achieved in these experiments (data not shown). The implication is that the lack of desensitisation of endogenous GnRH-R may be essential for such direct antiproliferative effects, and that endogenous desensitising type II receptors would therefore be unlikely to mediate inhibition of proliferation.

\section{Overview}

The GnRH-Rs appear to have undergone a relatively recent period of rapidly accelerated molecular evolution that may have been important for the development of mammalian reproductive strategies, and the unanticipated characteristics of these receptors have provided unique opportunities for investigation - notably, the opportunities to explore the relationship between receptor structure and function, within the context of normal (non-mutated) GPCRs, and to study post-receptor adaptive mechanisms (in the absence of receptor desensitisation). Although relatively few GnRH-Rs have been investigated in detail, the available data imply that type II GnRH-Rs follow the general scheme outlined in Figure 2, whereas type I GnRH-Rs do not, and that the presence or absence of C-terminal tails is the major functional determinant of this dichotomy. We are now faced with a number of fundamental questions, including (a) what are the physiological roles of the type II GnRH-R, (b) how are type I GnRH-Rs targeted for $\beta$-arrestin-independent but CCVmediated internalisation, (c) does the binding to $\beta$-arrestin increase the range of signalling pathways regulated by type II GnRH-Rs, and (d) does the resistance of type I GnRH-Rs to desensitisation leave them particularly suited as targets for inhibition of proliferation in hormonedependent cancer cells? Clearly, a great deal is yet to be learned from study of these unique GPCRs.

\section{Acknowledgements}

This work was supported by grants from the Wellcome Trust $(054949,059795,062918)$ and Medical Research Council (G78/6046).

\section{References}

Barbieri RL 1992 Clinical application of GnRH and its analogues. Trends in Endocrinology and Metabolism 3 30-34.

Bernard O, Naor Z \& Sefer R 2001 Role of dynamin, Src, and ras in the protein kinase C-mediated activation of ERK by gonadotrophin-releasing hormone. Journal of Biological Chemistry 276 4554-4563.

Blomenrohr M, Heding A, Sellar R, Leurs R, Bogerd J, Eidne KA \& Willars GB 1999 Pivotal role for the cytoplasmic carboxyl-terminal tail of a nonmammalian gonadotrophin-releasing hormone receptor in cell surface expression, ligand binding, and receptor phosphorylation and internalisation. Molecular Pharmacology 56 1229-1237.

Conn PM \& Crowley Jr WF 1994 Gonadotrophin-releasing hormone and its analogs. Annual Review of Medicine 45 391-405.

Conn PM, Huckle WR, Andrews WV \& McArdle CA 1987 The molecular mechanism of action of gonadotrophin hormone releasing hormone $(\mathrm{GnRH})$ in the pituitary. Recent Progress in Hormone Research 43 29-68.

Daaka Y, Luttrell LM, Ahn S, Della Rocca GJ, Ferguson SS, Caron MG \& Lefkowitz RJ 1998 Essential role for G protein-coupled receptor endocytosis in the activation of mitogen-activated protein kinase. Journal of Biological Chemistry 273 685-688.

Davidson JS, Wakefield IK \& Millar RP 1994 Absence of rapid desensitisation of the mouse gonadotrophin-releasing hormone receptor. Biochemical Journal 300 299-302.

Eidne KA, Flanagan CA \& Millar RP 1985 Gonadotrophin-releasing hormone binding sites in human breast carcinoma. Science 229 989-991.

Emons G \& Schally AV 1994 The use of luteinising hormone releasing hormone agonists and antagonists in gynaecological cancers. Human Reproduction 9 1364-1379.

Emons G, Schroder B, Ortmann O, Westphalen S, Schulz KD \& Schally AV 1993 High affinity binding and direct antiproliferative effects of luteinising hormone-releasing hormone analogs in human endometrial cancer cell lines. Journal of Clinical Endocrinology and Metabolism 77 1458-1464.

Emons G, Ortmann O, Schulz KD \& Schally AV 1997 Growth inhibitory actions of analogues of luteinising hormone releasing hormone on tumour cells. Trends in Endocrinology and Metabolism 8 355-362. 
Emons G, Muller V, Ortmann O \& Schulz KD 1998 Effects of LHRH-analogues on mitogenic signal transduction in cancer cells. Journal of Steroid Biochemistry and Molecular Biology 65 199-206.

Evans JJ, Forrest-Owen W \& McArdle CA 1997 Oxytocin receptor-mediated activation of phosphoinositidase $\mathrm{C}$ and elevation of cytosolic calcium in the gonadotroph-derived alphaT3-1 cell line. Endocrinology 138 2049-2055.

Everest HM, Hislop JN, Harding T, Uney JB, Flynn A, Millar RP \& McArdle CA 2001 Signalling and anti-proliferative effects mediated by gonadotrophin-releasing hormone receptors after expression in breast cancer cells using recombinant adenovirus. Endocrinology 142 4663-4672.

Ferguson SS 2001 Evolving concepts in G-protein-coupled receptor endocytosis: the role in receptor desensitisation and signalling. Pharmacological Reviews 53 1-24.

Forrest-Owen W, Willars GB, Nahorski SR, Assefa D, Davidson JS, Hislop J \& McArdle CA 1999 The lack of gonadotrophin-releasing hormone $(\mathrm{GnRH})$ receptor desensitisation in $\alpha \mathrm{T} 3-1$ cells is not due to GnRH receptor reserve or phosphatidylinositol 4,5-bisphosphate pool size. Molecular and Cellular Endocrinology 147 161-173.

Goodman OBJ, Krupnick SG, Santini F, Gurevich VV, Penn RB, Gagnou AW, Kenn JH \& Benovic JL 1996 Beta arrestin acts as a clathrin adapter in endocytosis of the beta 2 adrenergic receptor. Nature 383 447-450.

Grundker C, Volker P \& Emons G 2001 Antiproliferative signalling of luteinising hormone-releasing hormone in human endometrial and ovarian cancer cells through $\mathrm{G}$ protein alpha(I)-mediated activation of phosphotyrosine phosphatase. Endocrinology 142 2369-2380.

Hanyaloglu AC, Vrecl M, Kroeger KM, Miles LE, Qian H, Thomas WG \& Eidne KA 2001 Casein kinase II sites in the intracellular C-terminal domain of the thyrotropin-releasing hormone receptor and chimeric gonadotrophin-releasing hormone receptors contribute to beta-arrestin-dependent internalisation. Journal of Biological Chemistry 276 18066-18074.

Heding A, Vrecl M, Bogerd J, McGregor A, Sellar R, Taylor PL \& Eidne KA 1998 Gonadotrophin-releasing hormone receptors with intracellular carboxyl-terminal tails undergo acute desensitisation of total inositol phosphate production and exhibit accelerated internalisation kinetics. Journal of Biological Chemistry 273 11472-11477.

Heding A, Vrecl M, Hanyaloglu AC, Sellar R, Taylor PL \& Eidne KA 2000 The rat gonadotrophin-releasing hormone receptor internalises via a beta-arrestin-independent, but dynamindependent, pathway: addition of a carboxyl-terminal tail confers beta-arrestin dependency. Endocrinology 141 299-306.

Hislop JN, Madziva MT, Everest HM, Harding T, Uney JB, Willars GB, Millar RP, Troskie BE, Davidson JS \& McArdle CA 2000 Desensitisation and internalisation of human and xenopus gonadotrophin-releasing hormone receptors expressed in alphaT4 pituitary cells using recombinant adenovirus. Endocrinology 141 4564-4575.

Hislop JN, Everest HM, Harding T, Uney JB, Troskie BE, Millar RP \& McArdle CA 2001 Differential internalisation of mammalian and non-mammalian gonadotrophin-hormone releasing hormone receptors: uncoupling of dynamin-dependent internalisation from mitogen-activated protein kinase signalling. Journal of Biological Chemistry 276 39685-39694.

Imai A \& Tamaya T 2000 GnRH receptor and apoptotic signalling. Vitamins and Hormones 59 1-33.

Imai A, Horibe S, Takagi A \& Tamaya T 1997 Gi protein activation of gonadotrophin-releasing hormone-mediated protein dephosphorylation in human endometrial carcinoma. American Journal of Obstetrics and Gynecology 176 371-376.

Jennes L, Stumpf WE \& Conn PM 1983 Intracellular pathways of electron-opaque gonadotrophin-releasing hormone derivatives bound by cultured gonadotrophs. Endocrinology 113 1683-1689.
Jennes L, Coy D \& Conn PM 1986 Receptor-mediated uptake of GnRH agonist and antagonists by cultured gonadotrophs: evidence for differential intracellular routing. Peptides 7 459-463.

Kakar SS 1998 Inhibition of growth and proliferation of EcRG293 cell line expressing high-affinity gonadotrophin-releasing hormone $(\mathrm{GnRH})$ receptor under the control of an inducible promoter by $\mathrm{GnRH}$ agonist (Dlys6)GnRH and antagonist (Antide). Cancer Research 58 4558-4560.

Kakar SS, Grizzle WE \& Neill JD 1994 The nucleotide sequences of human GnRH receptors in breast and ovarian tumors are identical with that found in pituitary. Molecular and Cellular Endocrinology 106 145-149.

Kakar SS, Nath S, Bunn J \& Jennes L 1997 The inhibition of growth and down-regulation of gonadotrophin releasing hormone $(\mathrm{GnRH})$ receptor in alphaT3-1 cells by GnRH agonist. Anticancer Drugs $\mathbf{8}$ 369-375.

Kranenburg O, Verlaan I \& Moolenaar WH 1999 Dynamin is required for the activation of mitogen-activated protein (MAP) kinase by MAP kinase kinase. Journal of Biological Chemistry 274 35301-35304.

Lefkowitz RJ 1996 G protein-coupled receptors and receptor kinases: from molecular biology to potential therapeutic applications. Nature Biotechnology 14 283-286.

Liggett SB, Bouvier M, Hausdorff WP, O'Dowd B, Caron MG \& Lefkowitz RJ 1989 Altered patterns of agonist-stimulated cAMP accumulation in cells expressing mutant beta 2 -adrenergic receptors lacking phosphorylation sites. Molecular Pharmacology 36 641-646.

Limonta P, Moretti RM, Marelli MM, Dondi D, Parenti M \& Motta M 1999 The luteinising hormone-releasing hormone receptor in human prostate cancer cells: messenger ribonucleic acid expression, molecular size, and signal transduction pathway. Endocrinology 140 $5250-5256$.

Limonta P, Marelli MM \& Moretti RM 2001 LHRH analogues as anticancer agents: pituitary and extrapituitary sites of action. Expert Opinion on Investigational Drugs 10 709-720.

Luttrell LM, Roudabush FL, Choy EW, Miller WE, Field ME, Pierce KL \& Lefkowitz RJ 2001 Activation and targeting of extracellular signal-regulated kinases by beta-arrestin scaffolds. PNAS $\mathbf{9 8}$ 2449-2454.

McArdle CA \& Forrest-Owen W 1997 Pituitary adenylate cyclase-activating polypeptide (PACAP) actions on alphaT3-1 gonadotrophs show desensitisation. Journal of Neuroendocrinology 9 893-901.

McArdle CA, Bunting R \& Mason W 1992 Dynamic video imaging of $\mathrm{Ca}^{2+}$ in the $\alpha \mathrm{T} 3-1$ gonadotroph-derived cell line. Molecular and Cellular Neurosciences 3 124-132.

McArdle CA, Forrest-Owen W, Willars G, Davidson J, Poch A \& Kratzmeier M 1995 Desensitisation of gonadotrophin-releasing hormone action in the gonadotroph-derived alpha T3-1 cell line. Endocrinology 136 4864-4871.

McArdle CA, Willars GB, Fowkes RC, Nahorski SR, Davidson JS \& Forrest-Owen W 1996 Desensitisation of gonadotrophin-releasing hormone action in alphaT3-1 cells due to uncoupling of inositol 1,4,5-trisphosphate generation and $\mathrm{Ca}^{2+}$ mobilisation. Journal of Biological Chemistry 271 23711-23717.

McArdle CA, Davidson JS \& Willars GB 1999 The tail of the gonadotrophin-releasing hormone receptor: desensitisation at, and distal to, G protein-coupled receptors. Molecular and Cellular Endocrinology 151 129-136.

Millar RP, Sealfon SC, Flanagan CA, Ott TR, Lowe S, Troskie BE, Faurholm B \& Katz A 2000 The structure and function of GnRHs and their receptors. Proceedings of the Endocrine Society, Toronto, Canada. Abstract 98.

Millar RP, Lowe S, Conklin D, Pawson A, Maudsley S, Troskie B, Ott T, Millar M, Lincoln G, Sellar R, Faurholm B, Scobie G, Kuestner R, Terasawa E \& Katz A 2001 A novel mammalian receptor for the evolutionarily conserved type II GnRH. PNAS $\mathbf{9 8}$ 9636-9641. 
Miller WE \& Lefkowitz RJ 2001 Expanding roles for beta-arrestins as scaffolds and adapters in GPCR signalling and trafficking. Current Opinion in Cell Biology 13 139-145.

Miller WR, Scott WN, Morris R, Fraser HM \& Sharpe RM 1985 Growth of human breast cancer cells inhibited by a luteinising hormone-releasing hormone agonist. Nature 313 231-233.

Naor Z, Capponi AM, Rossier MF, Ayalon D \& Limor R 1988 Gonadotrophin-releasing hormone-induced rise in cytosolic free $\mathrm{Ca} 2+$ levels: mobilization of cellular and extracellular $\mathrm{Ca} 2+$ pools and relationship to gonadotrophin secretion. Molecular Endocrinology 2 512-520.

Naor Z, Benard O \& Seger R 2000 Activation of MAPK cascades by G-protein-coupled receptors: the case of gonadotrophin-releasing hormone receptor. Trends in Endocrinology and Metabolism 11 91-99.

Neill JD, Duck LW, Musgrove LC \& Sellers JC 1998 Potential regulatory roles for $\mathrm{G}$ protein-coupled receptor kinases and beta-arrestins in gonadotrophin-releasing hormone receptor signaling. Endocrinology 139 1781-1788.

Neill JD, Musgrove LC, Duck LW \& Sellers JC 1999 High efficiency method for gene transfer in normal pituitary gonadotropes: adenoviral-mediated expression of $\mathrm{G}$ protein-coupled receptor kinase 2 suppresses luteinizing hormone secretion. Endocrinology 140 $2562-2569$

Neill JD, Duck LW, Sellers JC \& Musgrove LC 2001a A gonadotrophin-releasing hormone $(\mathrm{GnRH})$ receptor specific for GnRH II in primates. Biochemical and Biophysical Research Communications 282 1012-1018.

Neill JD, Musgrove LC, Sellers JC \& Duck LW $2001 b$ A new form of the GnRH receptor (h-GnRH-R II) is encoded in the human genome, expressed by the pituitary, and resembles the type II GnRH-R of non-mammals. Proceedings of the Endocrine Society, 83rd Annual Meeting, Denver, CO, USA. p 256 (abstract).

Schally AV 1999 LH-RH analogues: I. Their impact on reproductive medicine. Gynecological Endocrinology 13 401-409.

Schally AV \& Nagy A 1999 Cancer chemotherapy based on targeting of cytotoxic peptide conjugates to their receptors on tumors. European Journal of Endocrinology 141 1-14.

Schmid SL, McNiven MA \& De Camilli P 1998 Dynamin and its partners: a progress report. Current Opinion in Cell Biology 10 504-512.

Schomerus E, Poch A, Bunting R, Mason WT \& McArdle CA 1994 Effects of pituitary adenylate cyclase-activating polypeptide in the pituitary: activation of two signal transduction pathways in the gonadotrope-derived $\alpha \mathrm{T} 3-1$ cell line. Endocrinology 134 315-323.

Sealfon SC, Weinstein H \& Millar RP 1997 Molecular mechanisms of ligand interaction with the gonadotrophin-releasing hormone receptor. Endocrine Reviews 18 180-205.

Stojilkovic SS \& Catt KJ 1995 Expression and signal transduction pathways of gonadotrophin-releasing hormone receptors. Recent Progress in Hormone Research 50 161-205.

Sun YM, Flanagan CA, Illing N, Ott TR, Sellar R, Fromme BJ, Hapgood J, Sharp P, Sealfon SC \& Millar RP 2001 A chicken gonadotrophin-releasing hormone receptor that confers agonist activity to mammalian antagonists. Identification of D-Lys(6) in the ligand and extracellular loop two of the receptor as determinants. Journal of Biological Chemistry 276 7754-7761.

Tobin AB, Totty NF, Sterlin AE \& Nahorski SR 1997 Stimulusdependent phosphorylation of G-protein-coupled receptors by casein kinase 1 alpha. Journal of Biological Chemistry 272 20844-20849.

Troski BE, Hapgood JP, Millar RP \& Illing N 2000 Complementary deoxyribonucleic acid cloning, gene expression, and ligand selectivity of a novel gonadotrophin-releasing hormone receptor expressed in the pituitary and midbrain of Xenopus laevis. Endocrinology 141 1764-1771.

Vieira AV, Lamaze C \& Schmid SL 1996 Control of EGF receptor signalling by clathrin-mediated endocytosis. Science 274 2086-2089.

Vrecl M, Anderson L, Hanyaloglu A, McGregor AM, Groarke AD, Milligan G, Taylor PL, Eidne KA 1998 Agonist-induced endocytosis and recycling of the gonadotrophin-releasing hormone receptor: effect of beta-arrestin on internalisation kinetics. Molecular Endocrinology 12 1818-1829.

Willars GB, McArdle CA \& Nahorski SR 1998 Acute desensitisation of phospholipase C-coupled muscarinic M3 receptors but not gonadotrophin-releasing hormone receptors co-expressed in alpha T3-1 cells: implications for mechanisms of rapid desensitisation. Biochemical Journal 333 301-308.

Willars GB, Heding A, Vrecl M, Sellar R, Blomenrohr M, Nahorski SR \& Eidne KA 1999 Lack of a C-terminal tail in the mammalian gonadotrophin-releasing hormone receptor confers resistance to agonist-dependent phosphorylation and rapid desensitisation. Journal of Biological Chemistry 274 30146-30153.

Willars GB, Royall JE, Nahorski SR, El Gehani F, Everest H \& McArdle CA 2001 Rapid down-regulation of the type I inositol 1,4,5-trisphosphate receptor and desensitisation of gonadotrophin-releasing hormone-mediated $\mathrm{Ca}^{2+}$ responses in alpha T3-1 gonadotrophs. Journal of Biological Chemistry 276 3123-3129.

Wojcikiewicz RJ \& Oberdorf JA 1996 Degradation of inositol 1,4,5-trisphosphate receptors during cell stimulation is a specific process mediated by cystein protease activity. Journal of Biological Chemistry 271 16652-16655.

Zhang J, Ferguson SS, Barak LS, Aber MJ, Giros B, Lefkowitz RJ \& Caron MG 1997 Molecular mechanisms of G protein-coupled receptor signalling: role of $\mathrm{G}$ protein-coupled receptor kinases and arrestins in receptor desensitisation and resensitization. Receptors and Channels 5 193-199.

Zhang T, Mulvaney JM \& Roberson MS 2001 Activation of mitogen-activated protein kinase phosphatase 2 by gonadotrophin-releasing hormone. Molecular and Cellular Endocrinology 172 79-89.

Zhu CC \& Wojcikiewicz RJ 2000 Ligand binding directly stimulates ubiquitinylation of the inositol 1,4,5-trisphosphate receptor. Biochemical Journal 15 551-556.

Received 17 September 2001 Accepted 23 November 2001 